\title{
FORMATION OF CAPABLE LOCAL SELF-GOVERNMENT IN UKRAINE AND EUROPEAN STANDARDS
}

\author{
Bilash O. V.
}

\section{INTRODUCTION}

A global trend in the process of formation and development of democratic systems is the growing role of local self-government in the structure of Public Administration bodies. It is particularly clear in countries with stable democratic traditions and developed socially oriented economies. In particular in all Western European countries, without exception, in the process of their movement to a united Europe, this trend was manifested in the transition of administrative territories from mainly an object to a subject of management up to obtaining the status of a subject that is self-governing. In other words, a legal and socio-economic environment is formed, in which there is actually sufficient legal, organizational and economic independence of a community or administrative-territorial unit. Moreover, this applies equally to countries with both unitary and federal systems of government.

These processes are caused by the following circumstances:

- interregional interdependence is growing;

- the regional factor in environmental problems and the urgent need to solve them have significantly increased;

- regional production, social structure and infrastructure have become more complex;

- the territorial division of labor with its international segment is deepening.

These factors are inherent in Ukraine today. It is quite appropriate to note that for new democratic states, which do not have well-established traditions and legal mechanisms for implementing legal values, the transformation and reform of the mechanism of public administration has become a permanent process ${ }^{1}$. It is quite obvious that in line the transformations that are taking place in the state, and consistent entry into the world and, first of all, the European legal space, interest in the transformations taking place in this region is naturally increasing. We are talking about reforming the system of

${ }^{1}$ Карабін Т.О. Компетенція місцевих органів державної виконавчої влади та органів місцевого самоврядування: теоретико-термінологічні аспекти. Держава і право. 2005. Вип. 29. С. 221. 
self-government and territorial structure, including improving the forms and methods of implementing local self-government, problems of forming and using local budgets, changing the role of local self-government bodies in the socio-economic development of territories and providing public services to the population. At the same time, to a large extent, interest is shown in finding a proper balance of power between central and local authorities, as well as between state authorities and local self-government bodies.

\section{The principle of subsidiarity as an indispensable condition for improving the public administration system}

The successful solution of these problems is largely due to the fact that the state policy is based on the principle of subsidiarity, provided for by the European Charter of local self-government, ratified by Ukraine ${ }^{2}$. The above principle of subsidiarity means, on the one hand, the rule of limitation of powers, when the limits of competence of a particular level of authorities are established by a ban on taking over the exercise of those powers that can be effectively resolved at a lower level. On the other hand, subsidiarity directly implies interference by higher-level authorities in the sphere of lower-level power, but such interference does not involve substitution, but a certain type of assistance, the purpose of which is to encourage grassroots authorities and empower them.

The principle of subsidiarity in modern Ukrainian legal research is considered as an important principle of organizing public power institutions in general, not only local self-government bodies. In recent years, a number of scientific developments have been published on this issue in Ukraine. At the same time, it is absolutely true that attempts to introduce the principle of subsidiarity into the legislative framework in many cases face great difficulties and do not receive logical development and pose a serious problem of interaction between existing levels of government in the state ${ }^{3}$. The lack of legislative consolidation, of course, is associated with the complexity of determining the theoretical and legal content of the principle of subsidiarity.

Regulatory regulation of the principle of subsidiarity in Ukrainian legislation is carried out only in separate acts, mainly of a programmatic nature. For the first time in domestic regulatory acts, the application of the principle of subsidiarity was reflected in the government decree of July 21 , 2006 "On approval of the state strategy for regional development for the

2 The charter was ratified by the law of Ukraine "On ratification of the European Charter of local self-government”. No. 452/97 dated 15.07.1997.

${ }^{3}$ Мошак О.В. Правовий зміст принципу субсидіарності в умовах євроінтеграції України. LEX PORTUS. № 3(5). 2017. C. 40. 
period up to 2015". However, a holistic interpretation of the concept of "subsidiarity" is contained in the state strategy for regional development for the period up to 2020, which was adopted after the implementation of the previous one. Thus, here subsidiarity is defined as the decentralization of power, its transfer to other bodies at the lowest level of Management, which can implement them most effectively ${ }^{4}$.

We believe that the idea that "in the light of the understanding of administrative law as a form of concretization of constitutional values and principles and legal regulation, the principle of subsidiarity primarily determines the proper detail of the organization and procedure of the relevant institutions of public power" ${ }^{2}$. Therefore, it seems that solving problems at the lowest and farthest level from the center should become a real guarantee of ensuring democracy at the local level of the activities of public administration bodies.

At the same time, since the content of the principle of subsidiarity implies the presence of positive responsibilities of higher-level authorities in relation to lower ones, the so-called "positive autonomy", in some cases it may contradict the principle of strict exclusivity of the competence of public administration bodies and officials. Accordingly, its justification and application in the practice of public administration determines loyalty to the idea that there may be two or more jurisdictions.

The scientific, theoretical and practical significance of the processes of improving the organization and activities of public administration bodies at the local level sets researchers the task of constantly monitoring the world practice of functioning of local self-government, tracking the results of scientific research on this issue.

Although for local executive authorities and local self - government bodies the object of managerial influence is the same - a certain administrative territory, there is a fundamentally different functional purpose, which is assigned to these two subsystems of public authorities. If local public administration ensures the implementation of national interests and guarantees the achievement of minimum social standards focused on average needs, which are fixed by the state, then local self-government

${ }^{4}$ Про затвердження Державної стратегії регіонального розвитку на період до 2020 року : Постанова Кабінету Міністрів України від 06.08.2014 р. № 385. URL : https://zakon.rada.gov.ua/laws/show/385-2014-\%D0\%BF (accessed: 28.12.2020).

5 Упровадження децентралізації публічної влади в Україні: національний і міжнародний аспекти / Г.Г. Динис, Т.О. Карабін, Я.В. Лазур та ін.; за заг. ред. д-ра юрид. наук, проф. М.В. Савчина. Ужгород : TIMPANI, 2015. С. 91.

${ }^{6}$ Blank, Y. Federalism, Subsidiarity, and the Role of Local Governments in an Age of Global Multilevel Governance. Fordham Urban Law Journal. Volume 37, Issue 2. 2009. P. 533. 
bodies act primarily in the interests of the local population and their activities are more fully aimed at providing public services to the residents of the community. At the community level, residents have more opportunities to influence the level and state of provision of public services at the local level (medical support, educational services, etc.).

Therefore, in cases where the consumption of a certain public good is limited to the circle of residents of a particular administrative-territorial unit, it is economically expedient and legally justified to transfer administrative powers to local self-government bodies to ensure the provision of appropriate public services to citizens. Conversely, limiting the competence of local self-government bodies and transferring powers to a higher organizational level of management is advisable only if the consumers of services are residents of several regions or administrative territories, or when it is possible to reduce the cost of resources (material, human, information) by increasing the scale of providing such services.

However, even in this case, the total effectiveness of the redistribution of powers "from bottom to top" will be determined by how much more savings will be due to the increase in the scale of providing public goods from additional costs in their provision. This understanding of the principle of subsidiarity is the basis for the process of improving the system of public administration, state administration and local self-government in European countries.

\section{The experience in organizing self-government in certain European countries}

Law No. 82-813 of March 2, 1982 became a regulatory document that, in France, actually began the long-term reform of Public Administration and local self-government ${ }^{7}$. This is known as the "decentralization law". The law provides for significant changes in the ratio of powers between the central government and local bodies; distribution of state resources based on new rules of local taxation and lending to local collectives; Administrative Organization of regions, etc. This reform of local government and selfgovernment in France has completed the improvement of the administrative and territorial structure of the country.

Currently, Local Self-Government in France is regulated by the Constitution of the Republic, the General Code of administrative-territorial entities $^{8}$, the Administrative Code of France ${ }^{9}$ and the code of communes ${ }^{10}$.

\footnotetext{
${ }^{7}$ Брэбан Г. Французское административное право. Москва: Прогресс, 1988. С. 75.

${ }^{8}$ Code general des collectivités territoriales. URL : https://www.legifrance.gouv.fr/ codes/texte_lc/LEGITEXT000006070633/(accessed: 28.12.2020).

${ }_{9}$ Адміністративний кодекс Франції. Закони про місцеве самоврядування / пер. 3 фр. Київ : ПСП, 1995.
} 
The financial independence of communities is a necessary prerequisite for the development of local self-government, so local authorities use local financial resources generated at the expense of taxes and fees to carry out their activities ${ }^{11}$.

In accordance with the current legislation, preliminary control over decisions of local authorities has been abolished. Control is carried out only for compliance of decisions of local bodies with the legislative framework. The reform provides for a significant expansion of the powers of local selfgovernment bodies by transferring the functions of state bodies to them. Local self-government in France in its current state is characterized by a relatively high level of autonomy of its institutions in solving problems of local significance. This is reflected in the presence of local elected bodies and their independent competence ${ }^{12}$.

A special feature of the organization of local self-government at the level of departments in France is the presence of an official of the prefect, who is both a representative of the state and a local self-government body in the department. He is the first official in the hierarchy of the department, and acting on behalf of the state, the prefect controls the provision of national interests, controls the exercise of the powers of central state bodies in the department, organizes government - department communication, and is responsible for managing state-owned property. The prefect also implements government policy, oversees the implementation of state government regulations in the department, and has the right to make decisions on the use of coercion by the police in order to ensure order ${ }^{13}$.

An important role in the system of local self-government in France is played by the system of inter-municipal government bodies. At the commune level, syndicates occupy a decisive place in this regard. Their main goal is to form inter-communal relations aimed at saving resources and improving the efficiency of Management in various spheres of life, improving the quality of service provision.

In the development of territorial administration in the UK over the past decades, two trends can be clearly traced. The first one is characterized by

10 Code des lois sur l'administration municipale de France. URL : http://www.viepublique.fr/actualite/dossier/municipales2008/ competencesobligationsmaires.html (accessed: 28.12.2020).

11 Чиркін А., Кушнір В. Особливості місцевого самоврядування Франції. Підприємство, господарство і право. 2020. № 5. С. 177.

12 Евдокимов В.Б, Старцев Я.Ю. Местные органы власти зарубежных стран. Правовые аспекты. Москва, 2001. С. 102.

${ }^{13}$ Гробова В.П. Система місцевого самоврядування Франції: досвід для України. Науковий вісник Ужгородського національного університету. 2015. Серія Право. Випуск 32. Том 1. С. 110. 
gradual decentralization of administration. The fundamental principle of its implementation is decision-making, if possible, at the lowest administrative and managerial level, provided that a competent solution to a particular problem is possible at this level. At the same time, the second trend is being implemented, which concerns strengthening control over the activities of local bodies by the central government. Control is mainly reduced to economic levers and concerns the problems of saving resources, achieving maximum effect while minimizing costs. This is facilitated by the policy of local administrative bodies in their activities to use an approach that can be formulated as follows: "from administration to management" 14 . Currently, the main tasks of local administrative bodies include the following: solving social problems in the territory under their jurisdiction, which include education, healthcare, ensuring public order, Environmental Protection, comprehensive support for the development of the territory, and so on.

Local governments in the UK today have a fairly wide "corridor of freedom" in the performance of their official duties. Most of them use a system of committees, in which the council determines only the policy and general principles of the body's activities, and specialized committees, which are formed from deputies, directly manage the relevant services. The council is responsible for delegating any function to the committee, with the exception of those related to loans, local tax administration, or financial requirements to other local authorities.

At the same time, it should be noted that it is mandatory for local governments in the UK to fully and consistently apply national indicators, standards, priorities and goals. Local self-government bodies are required to take into account the system of public service contracts and goals defined by the government in accordance with the National Public Service Contract for local self-government bodies.

In Sweden, local authorities are represented by two levels: 21 Lens (districts) and 290 communes (municipalities) ${ }^{15}$. Each Len has a separate local regional elected body of len, which is responsible for local taxes, health care organization, Education, Culture, and so on ${ }^{16}$. Local and regional self - government bodies have elected bodies-assemblies or councils and administrations-that make decisions, but a lot of powers are delegated to the local authorities. Each commune also has an elected local self - government body-the commune council. In Sweden, there are about 20 municipal associations, which are divided

14 Административное право зарубежных стран / Под ред. А.Н. Козырина, М.А. Штатиной. Москва : Спарк, 2003. С. 338.

15 Шведський погляд на нагляд у місцевому самоврядуванні. URL : https://decentralization.gov.ua/news/12460 (accessed: 28.12.2020).

${ }^{16}$ Ермошенко Н.Н. Опыт самоуправления территорий за рубежом. Київ, 1992. С. 23. 
into 10 industries. Their areas of activity are regional planning, water management, fire service, problems of combating alcoholism and drug addiction, wastewater treatment systems, public transport, etc.

In percentage terms, more than 70 percent of services are provided by local or regional authorities, so the state does not have such a close relationship with citizens. Such services are provided by regional and local authorities. General powers relate to cultural events, public services, industrial services, transport, water supply and sewerage, provision of electricity, fuel, maintenance of streets and parks, environmental protection and trade. The special powers of communes are quite broad. They are defined by 20 legislative acts, including on education, social services for the population, on medicine and medical care, and so on. Communes assume most of the functions that directly concern the population as a whole and each resident in particular. First of all, this applies to the educational and social spheres.

But not only in the social sphere, communes in Sweden have quite broad powers. They have the opportunity to support private firms in the event that, for example, their bankruptcy may lead to an increase in unemployment in a particular area. The influence of communes is also resolved when it is necessary to provide guarantees of the minimum level of trade services that should be provided to certain categories of the population. This is especially true in rural areas.

Communes have broad powers to conduct general activities on their territory in relation to industry and trade. This applies to the placement of industrial enterprises, leasing of fixed assets, encouraging local enterprises to increase employment, and so on. According to the current legislation, communes and len municipalities are required to manage their property in such a way that it is not reduced, and the need for funds must be covered by taxes to the extent that they cannot otherwise be met.

The organization and legal status of Public Administration bodies in the Federal Republic of Germany at the local level, the procedure for their formation and functioning are determined primarily by the constitutions and legislation of individual lands. Each of the lands is endowed with broad autonomy, which, first of all, is manifested by the fact that each of the lands has the right to determine the model of local self-government. For example, there are 5 different local organizations in Germany ${ }^{17}$. Although the current stage of development of the local self-government system is characterized by tendencies to unify models, and the defining criterion for classifying modern models of municipal administration is the criterion of belonging to the

${ }^{17}$ Гробова В.П. Особливості місцевого самоврядування в Німеччині. Науковий вісник Херсонського державного університету. Серія Юридичні науки. Випуск 3-2. Том 1. 2015. С. 31. 
governing competence of one of the two main authorities of the community (the council or the mayor) or its distribution between both subjects of power ${ }^{18}$.

In all German lands, self-government is developed, and more than 80 percent of issues related to the entry of citizens into legal relations with the authorities are resolved in communities. It should be noted that a fairly wide segment of powers in the socio-economic sphere of local authorities in Germany is guaranteed, first of all, by the existing institution of property. In particular, the property of local authorities in the municipal and credit spheres, in local transport, in housing construction. Communities own sewage treatment plants, farms, repair shops, and a significant proportion of structures that ensure the functioning of the industrial and social infrastructure of a city or a separate administrative territory. Community and land legislation in Germany provides for the possibility of participation of local authorities in joint-stock companies that exercise significant influence on the social sphere at their location.

An important element of ensuring the effective functioning of local authorities is the system of financial guarantees of local self-government, which are not limited to the proclamation of financial independence of communities and their associations. The consolidation of their powers in the financial sphere is accompanied by the obligation to provide financial assistance from the Federation, reimbursement by the Federation of expenses related to the performance of assigned tasks, the formation of the tax base of territorial utility corporations, taking into account the financial potential of communities and their associations in the implementation of the financial equalization policy ${ }^{19}$.

State regional administration and local self-government in Switzerland, in addition to the general trends that concern European countries, has significant differences and specifics. Local Government in Switzerland is relatively stable and unchangeable. A relatively small number of territorial changes have taken place over the centuries. However, recently local authorities, in particular, in small territorial units, have faced problems in fulfilling their tasks and providing rational and efficient services ${ }^{20}$.

In Switzerland, the fiscal autonomy of communities is obvious. Communities control their own finances, and they are also authorized to set

18 Красівський О.Я., Янишевський М.М. Еволюція системи місцевого самоврядування у Німеччині (на прикладі землі Бранденбург): історикоуправлінський аспект. Аспекти публічного управління. № 6-7(32-33). 2016. С. 90.

19 Гриценко Е.В. Правовые аспекты обеспечения гарантий местного самоуправления в Федеративной Республике Германии. Журнал Российского права. 2001. № 9. С. 98.

20 Децентралізація публічної влади: досвід європейських країн та перспективи України / Бориславська О., Заверуха I., Захарченко Е ., та ін.; швейцарськоукраїнський проект « підтримка децентралізації в Україні» DESPRO. Київ: ТОВ «Софія». 2012. С. 41. 
the local level of taxation, which is more than a third of the total taxes paid by citizens ${ }^{21}$.

It is also important that the Swiss Confederation is dominated by the principle of "direct democracy", that is, direct participation of voters in governance. It is implemented through referendums, which are systematically held both on a federal, cantonal and communal scale. The Federal Council, or government of the Canton, submits to a referendum all bills already adopted at the appropriate level, without exception, and only after their approval in a referendum do they enter into force.

What is important, in our opinion, is that each public organization or political party has the right to put forward its own draft law and put it to a vote, as well as to demand a referendum on a specific decision of the federal or cantonal government, provided that it gathers the necessary number of citizens under the petition. Thus, referendums and initiatives as procedures for direct lawmaking are the main levers of real democracy in Switzerland.

\section{Implementation of European standards of local self-government in the state practice of Ukraine}

In modern conditions, Ukraine is making powerful efforts to integrate into European structures, which is also manifested in the introduction of European standards of local self-government into domestic state practice. Therefore, it is extremely important to creatively use the existing experience of Europe, analyze the main European systems of local self-government, determine their features, reasonably applying them to the law of creation and law enforcement, while preserving the best original traditions of local selfgovernment.

In the modern Ukrainian realities of the state, the introduction of the principle of subsidiarity in the organization of Public Administration is a complex problem. The practical problem of distributing the powers of Public Administration based on the principle of subsidiarity is, first of all, to determine the maximum capabilities of power subjects of lower organizational levels ${ }^{22}$. In such a situation, the above has led to the question of optimizing the territorial organization of state power and local selfgovernment, replacing insufficiently capable, weak administrative-territorial units with self-sufficient levels of administration.

\footnotetext{
${ }^{21}$ Чернеженко О.М. Сучасний стан муніципальної системи Швейцарії. Науковий вісник Ужгородського національного університету. Серія Право. Випуск 31. Том 1. C. 106.

22 Карабін Т.О. Субсидіарність як вихідна ідея в розподілі повноважень публічної адміністрації. Науковий вісник Ужгородського національного університету. Серія Право. 2014. Вип. 29. Ч. 2. Т. 4/2. С. 62.
} 
What is important in building self-sufficient territorial communities is that the capacity of such communities should be not only resource, but also personnel, infrastructure, etc. Hence the idea of revising the territorial structure of the state, which is closely related to the possibility of ensuring the implementation of local self-government in a particular territorial community or region. After all, the effectiveness of the exercise of powers by public administration bodies is directly dependent on the administrativeterritorial structure of the state and the level of its validity. Because the administrative-territorial structure is not only the fundamental criterion that is used for the organization of subjects of public administration, but determines the content and types of procedures, determines the content and types of legal relations that arise between different subjects of public administration, affects the forms and content of relations between subjects of public administration, their mutual powers, the differentiation of these powers, determines the prevalence of administrative powers of subjects of public administration ${ }^{23}$. Therefore, all attempts to reform it in Ukraine without improving the administrative-territorial structure were in vain.

As for the characteristics, criteria and objective indicators of the viability of territorial communities, the methodology for forming capable territorial communities, approved by the government decree, is the normative act in Ukraine that clearly defines them. In particular, the formation of capable territorial communities is carried out taking into account:

- the ability of local self-government bodies to solve public issues that fall within their competence, to meet the needs of the population of the relevant administrative-territorial units;

- historical, geographical, socio-economic, Natural, Environmental, ethnic, cultural features of the development of the relevant administrativeterritorial units;

- the development of infrastructure of the relevant administrativeterritorial units;

- financial support of the relevant administrative-territorial units;

- labor migration of the population;

- the results of a preliminary assessment of the level of capability of territorial communities;

- optimal networks of social infrastructure and availability of public services in the relevant areas ${ }^{24}$.

23 Загальне адміністративне право : підручник / Гриценко І.С., Мельник Р.С., Пухтецька А.А. та інші ; за заг. ред. І.С. Гриценка. Київ : Юрінком Інтер, 2015. С. 187.

${ }^{24}$ Про внесення змін до Методики формування спроможних територіальних громад : Постанова Кабінету Міністрів України від 24.01.2020. № 34. URL : https://zakon.rada.gov.ua/laws/show/34-2020-\%D0\%BF\#Text (accessed: 28.12.2020). 
The criteria for assessing the level of capability include:

- the number of people permanently residing in the territory of a capable territorial community;

- the number of students receiving education in institutions of general secondary education located on the territory of a capable territorial community;

- the area of the territory of a capable territorial community; the tax capacity index of the budget of a capable territorial community,

- as well as the share of local taxes and fees in the budget revenues of a capable territorial community.

As for the issue of normative consolidation of the administrativeterritorial structure in Ukraine, despite numerous attempts to implement it, it has not yet found its legislative definition. Chronologically, the last legislative draft on the consolidation of the administrative-territorial structure was presented at the Ministry of regional development, construction and housing and communal services of Ukraine in $2014^{25}$. Its provisions defined the administrative-territorial structure of Ukraine as determined by geographical, historical, economic, social, cultural and other factors internal territorial organization of the state with the division of its territory into components - administrative-territorial units, in order to provide the population with the necessary level of public services, a rational system of management of socio-economic processes, balanced development of the entire territory of the state.

At the same time, despite the lack of a corresponding law, the reform of the administrative-territorial structure has been carried out in recent years. This reform concerned two levels of public administration organization: the community level and the district level.

Reform at the level of territorial communities took place during 20152020 by combining territorial communities into capable and self-sufficient ones in accordance with the provisions of the law of Ukraine "On voluntary association of territorial communities". The subjects of voluntary association of territorial communities were adjacent territorial communities of villages, towns, cities, and the state, in turn, established by law financial support for the voluntary association of territorial communities of villages, towns, cities and joining the United territorial communities by providing the United territorial community with funds in the form of subventions for the formation of appropriate infrastructure in accordance with the socioeconomic development plan of such a territorial community. During 2015-

25 Про адміністративно-територіальний устрій в Україні : Проект Закону України запропонований Інститутом громадянського суспільства. URL : http://municipal.gov.ua/news/show/id/1184 (accessed: 28.12.2020). 
2019, 982 united territorial communities were voluntarily formed in Ukraine, which included about 4,500 former local councils ${ }^{26}$. As of November 2020, local elections were held in 1,438 newly formed united territorial communities, that is, the ubiquity of the reform was ensured.

The reform of the second level of organization of public administration, namely, district administration, is associated with the adoption of a resolution by the parliament "on the formation and liquidation of districts" on July 17, 2020. As a result of its approval, 490 old districts were liquidated, but 136 new districts were formed. At the same time, only in 119 new districts in October of this year, local elections of Deputies of district councils were held, since the rest of them are located on the territory not controlled by Ukraine.

The transformation of territorial communities and administrativeterritorial entities from a subject to an object of management is also associated not only with the consolidation of local self-government bodies at the basic level and at the level of districts. The formation of self - sufficient and capable local self-government bodies is associated with giving bodies appropriate powers, and even more importantly-resources for the implementation of such powers.

Regarding the issue of financial decentralization, on December 15, 2020, the law of Ukraine "On the state budget of Ukraine for 2021" was adopted, which continued the processes of financial decentralization that had begun. In accordance with its provisions, the united territorial communities will have the same powers and resources. In particular, the positive aspect of this law is that the legislator transferred $60 \%$ of the personal income tax to the local level in the budgets of territorial communities ${ }^{27}$. We also consider it positive the transfer to local budgets of $100 \%$ of the excise tax on the sale of excisable goods by retail business entities, that is an important sign of the legislator's intentions to carry out real fiscal decentralization. In addition to these two national taxes and local taxes, local budgets have transferred $100 \%$ of the income tax of enterprises and financial institutions of communal ownership, rent for special use of forest resources of local significance, rent for special use of water bodies of local significance, rent for the use of subsurface resources for the extraction of minerals of local significance, 37\% of rent for special use of forest resources of state significance (logging of main use), $5 \%$ of rent for the use of subsurface resources for the extraction

${ }^{26}$ Результати першого етапу децентралізації в Україні 2014-2019 роки. URL : https://decentralization.gov.ua/about (accessed: 28.12.2020).

${ }^{27}$ Про Державний бюджет України на 2021 рік: Закон України від 15.12.2020. URL : https://w1.c1.rada.gov.ua/pls/zweb2/webproc4_1?pf3511=69938 (accessed: 26.12.2020). 
of minerals of national significance, 3\% of rent for the use of subsurface resources for the extraction of minerals of national significance, $3 \%$ of rent for the use of subsurface resources for the extraction of minerals of national significance gas condensate. We consider this another step towards the formation of real local self-government, which will actually be able to solve issues of local significance.

\section{CONCLUSIONS}

Proper organization of public administration, both at the national and local levels, is a key factor in democratic governance as well as economic development. Therefore, the reform of the public administration and administration system should also include the reform of local selfgovernment, be aimed at developing local and regional authorities, strengthening their organizational, legal and resource independence, increasing institutional transparency and accountability. It is important in this direction to ensure the European standards of organization and activity of local self-government bodies, which are defined in the European Charter of local self-government, acquis communautaire and in the direct practice of the activities of relevant bodies.

In Ukraine, the reform of local public administration bodies is associated with the consolidation of territorial communities and districts. In November 2020, local elections were held in 1,438 newly formed united territorial communities, which included about 4,500 former local councils.

Also, simultaneously with the completion of the administrative-territorial reform, fiscal reform, that is, budget decentralization, is being implemented. A significant part of individual taxes and fees has been transferred to the local level and the law of Ukraine "On the state budget of Ukraine for 2021" continued the processes of financial decentralization that had begun. The personal income tax, the excise tax on the sale of excisable goods by retail business entities, the income tax of enterprises and financial institutions of communal ownership, rent for special use of forest resources of local significance, rent for special use of water bodies of local significance, rent for the use of subsurface resources for the extraction of minerals of local significance, rent for special use of forest resources of state significance (logging of main use), rent for the use of subsurface resources for the extraction of minerals of national significance, rent for the use of subsurface resources for the extraction of minerals of national significance were partially or fully transferred to local budgets. Therefore the newly formed territorial communities will create their own financial departments and administer financial resources. The next step is land reform, continuation of educational and medical reforms. 


\section{SUMMARY}

The work is devoted to the study of legal regulation of the organization and implementation of local self-government in Ukraine. Emphasis is placed on the importance of European standards and requirements for building a proper system of public administration at the local level. The principle of subsidiarity and its content in the activities of local self-government bodies are studied. The work analyzes the peculiarities of the organization of local self-government in France, Germany, Sweden and Switzerland.

It is concluded that in Ukraine, the reform of local public administration bodies is associated with the consolidation of territorial communities and districts. It is proved that simultaneously with the completion of the administrative-territorial reform, fiscal reform, that is, budget decentralization, is being implemented. A significant part of individual taxes and fees has been transferred to the local level, and the newly formed territorial communities will create their own financial departments and administer financial resources. At the same time, to complete the reform that has begun, the land reform must be completed, and educational and medical reforms must continue.

\section{REFERENCES}

1. Blank, Y. Federalism, Subsidiarity, and the Role of Local Governments in an Age of Global Multilevel Governance. Fordham Urban Law Journal. Volume 37, Issue 2. 2009. Pp. 510-558.

2. Code des lois sur l'administration municipale de France. URL : http://www.viepublique.fr/actualite/dossier/municipales2008/ competencesobligationsmaires.html (accessed: 26.12.2020).

3. Code général des collectivités territoriales. URL : https://www.legifrance.gouv.fr/codes/texte_lc/LEGITEXT000006070633/ (accessed: 26.12.2020).

4. Административное право зарубежных стран / Под ред. А.Н. Козырина, М.А. Штатиной. Москва : Спарк, 2003. 462 с.

5. Адміністративний кодекс Франції. Закони про місцеве самоврядування / пер. $з$ фр. Київ : ПСП, 1995.

6. Брэбан Г. Французское административное право. Москва : Прогресс, 1988. 488 с.

7. Гриценко Е.В. Правовые аспекты обеспечения гарантий местного самоуправления в Федеративной Республике Германии. Журнал Российского права. 2001. № 9. С. 96-108.

8. Гробова В.П. Особливості місцевого самоврядування в Німеччині. Науковий вісник Херсонського державного університету. Серія Юридичні науки. Випуск 3-2. Том 1. 2015. С. 30-33. 
9. Гробова В.П. Система місцевого самоврядування Франції: досвід для України. Науковий вісник Ужгородського наџіонального університету. 2015. Серія Право. Випуск 32. Том 1. Рp. 108-112.

10. Децентралізація публічної влади: досвід європейських країн та перспективи України / Бориславська О., Заверуха I., Захарченко Е ., та ін.; швейцарсько-український проект «Підтримка децентралізації в Україні» DESPRO. Київ : TOB « Софія», 2012.

11. Евдокимов В.Б, Старцев Я.Ю. Местные органы власти зарубежных стран. Правовые аспекты. Москва, 2001. 251 с.

12. Ермошенко Н.Н. Опыт самоуправления территорий за рубежом. Київ, 1992. 56 с.

13. Загальне адміністративне право : підручник / Гриценко I.C., Мельник Р.С., Пухтецька А.А. та ін.; за заг. ред. І.С. Гриценка. Київ : Юрінком Інтер, 2015.

14. Карабін Т.О. Компетенція місцевих органів державної виконавчої влади та органів місцевого самоврядування: теоретикотермінологічні аспекти. Держава і право. 2005. Вип. 29. С. 221-228.

15. Карабін Т.О. Субсидіарність як вихідна ідея в розподілі повноважень публічної адміністрації. Науковий вісник Ужгородського національного університету. Серія Право. 2014. Вип. 29. Ч. 2. Т. 4/2. C. 60-63.

16. Красівський О.Я., Янишевський М.М. Еволюція системи місцевого самоврядування у Німеччині (на прикладі землі Бранденбург): історико-управлінський аспект. Аспекти публічного управління. № 6-7(32-33). 2016. С. 85-94.

17. Мошак О.В. Правовий зміст принципу субсидіарності в умовах євроінтеграції України. LEX PORTUS. № 3(5). 2017. С. 35-48.

18. Про адміністративно-територіальний устрій в Україні: Проект Закону України запропонований Інститутом громадянського суспільства. URL : http://municipal.gov.ua/news/show/id/1184 (accessed: 28.12.2020).

19. Про внесення змін до Методики формування спроможних територіальних громад : Постанова Кабінету Міністрів України від 24.01.2020. № 34. URL : https://zakon.rada.gov.ua/laws/show/34-2020\%D0\%BF\#Text (accessed: 28.12.2020).

20. Про Державний бюджет України на 2021 рік : Закон України від 15.12.2020.

URL

https://w1.c1.rada.gov.ua/pls/zweb2/webproc4_1?pf3511=69938 (accessed: 26.12.2020).

21. Про затвердження Державної стратегії регіонального розвитку на період до 2020 року : Постанова Кабінету Міністрів України від 
06.08.2014 p. № 385. URL : https://zakon.rada.gov.ua/laws/show/385-2014$\%$ D0\%BF (accessed: 28.12.2020).

22.Про ратифікацію Європейської хартії місцевого самоврядування : Закон України від 15.07.1997 р. № 452/97-ВР. URL : https://zakon.rada.gov.ua/laws/show/452/97-вp\#Text (accessed: 28.12.2020).

23. Результати першого етапу децентралізації в Україні 2014-2019 роки. URL : https://decentralization.gov.ua/about (accessed: 28.12.2020).

24. Упровадження децентралізації публічної влади в Україні: національний i міжнародний аспекти / Г.Г. Динис, Т.О. Карабін, Я.В. Лазур та ін. ; за заг. ред. д-ра юрид. наук, проф. М.В. Савчина. Ужгород : TIMPANI, 2015. $216 \mathrm{c.}$

25. Чернеженко О.M. Сучасний стан муніципальної системи Швейцарії. Науковий вісник Ужгородського національного університету. Серія Право. Випуск 31. Том 1. С. 105-111.

26. Чиркін А., Кушнір В. Особливості місцевого самоврядування Франції. Підприємство, господарство і право. 2020. № 5. Р. 176-180.

27. Шведський погляд на нагляд у місцевому самоврядуванні. URL : https://decentralization.gov.ua/news/12460 (accessed: 28.12.2020).

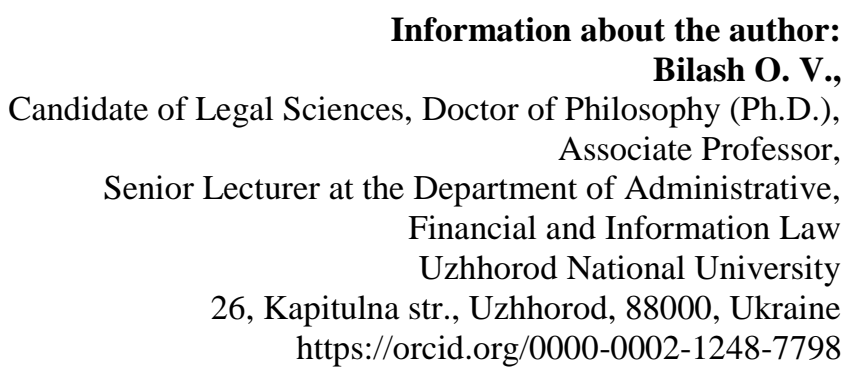

